\title{
An Efficient, Stereocontrolled Synthesis of the 25-(R)-Diastereomer of Dafachronic Acid A from $\beta$-Ergosterol
}

\author{
Simon Giroux and E. J. Corey* \\ Department of Chemistry and Chemical Biology, Harvard University, 12 Oxford Street \\ Cambridge, Massachusetts 02138
}

\section{Supporting Information}

Table of content:

1. Materials and Methods

2. Experimental procedures

3. References

4. Copies of selected ${ }^{1} \mathrm{H}$ and ${ }^{13} \mathrm{C}$ NMR spectras page $S 1$

page $S 2$

page S6

page $S 7$

1. Materials and Methods. Unless stated otherwise, reactions were performed in flamedried glassware under a positive pressure of nitrogen using freshly distilled dry solvents. Commercial grade reagents and solvents were used without further purification except as indicated below. $\mathrm{MeOH}$ was distilled over $\mathrm{CaSO}_{4}$. Dichloromethane was distilled from calcium hydride. Toluene, $\mathrm{Et}_{2} \mathrm{O}$ and THF were purified by Seco Solvent Systems. Thinlayer chromatography (TLC) was performed using E. Merck silica gel $60 \mathrm{~F}_{254}$ precoated plates $(0.25 \mathrm{~mm})$. Flash chromatography was performed using Baker silica gel (40 $\mu \mathrm{m}$ particle size). ${ }^{1} \mathrm{H}$ NMR spectra were recorded on Varian Mercury 400 (400 MHz) or Unity/INOVA $500(500 \mathrm{MHz})$ spectrometers and chemical shifts are reported in ppm from tetramethylsilane with the solvent resonance as internal standard ( $\delta 7.26 \mathrm{ppm}$ for $\left.\mathrm{CDCl}_{3}\right)$. ${ }^{13} \mathrm{C}$ NMR spectra were recorded on Varian Mercury $400(100 \mathrm{MHz})$ or Unity/INOVA 500 (125 MHz) spectrometers with proton decoupling. Chemical shifts are reported in ppm downfield from tetramethylsilane with the solvent as internal $\left(\delta 77.16 \mathrm{ppm}\right.$ for $\left.\mathrm{CDCl}_{3}\right)$. IR spectra were recorded on Avatar 360 FT-IR spectrometer. Low-resolution and highresolution mass spectral analyses were performed at the Harvard University Mass Spectrometry Center. Optical rotations were measured with a Perkin-Elmer 241 polarimeter

at the indicated temperature with a sodium lamp (D line, $589 \mathrm{~nm}$ ). Melting points (m.p.) are uncorrected and were recorded on a Thomas-Hoover Unimelt capillary melting point apparatus. 


\section{Experimental procedures.}

$\Delta^{7,22}$ benzoate (3).
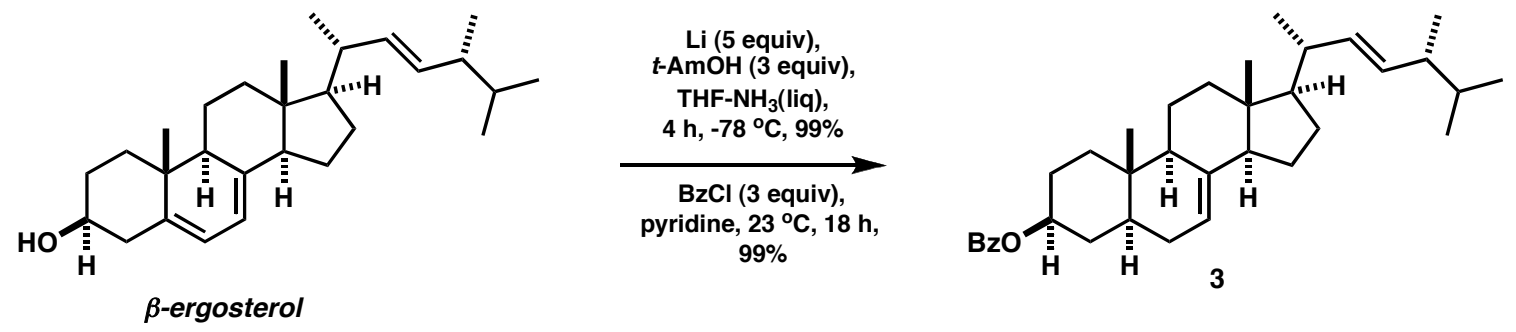

To a stirred deep-blue solution of $\mathrm{Li}\left(176 \mathrm{mg}, 25.0 \mathrm{mmol}, 5\right.$ equiv.) in $\mathrm{NH}_{3}$ (liq) (30 mL) at $-78{ }^{\circ} \mathrm{C}$ was slowly added a solution of $\beta$-ergosterol $(2.0 \mathrm{~g}, 5.0 \mathrm{mmol})$ and $t$ - $\mathrm{AmOH}(1.6$ $\mathrm{mL}, 15.0 \mathrm{mmol})$ in THF $(20 \mathrm{~mL})$. The resulting solution was stirred at $-78{ }^{\circ} \mathrm{C}$ for $4 \mathrm{~h}$. The excess of lithium was quenched very slowly by dropwise addition of isoprene until the blue color disappeared. The dry ice-acetone bath was removed and a strong flow of $\mathrm{N}_{2}$ was used to evaporate the $\mathrm{NH}_{3} \cdot \mathrm{H}_{2} \mathrm{O}(50 \mathrm{~mL})$ was then added and the two phases were separated. The aqueous phase was extracted with $\mathrm{Et}_{2} \mathrm{O}(3 \times 30 \mathrm{~mL})$ and the organic phase was dried with $\mathrm{Na}_{2} \mathrm{SO}_{4}$. Evaporation gave the corresponding $\Delta^{7,22}$ alcohol $(2 \mathrm{~g}, 99 \%)$ as a white solid which was directly used in the next step. To a stirred solution of this alcohol $(1.87 \mathrm{~g}, 4.7 \mathrm{mmol})$ in pyridine $(30 \mathrm{~mL})$ was added benzoyl chloride $(2.6 \mathrm{~mL}, 23.5 \mathrm{mmol})$ at $23{ }^{\circ} \mathrm{C}$. The resulting milky solution was stirred at $23{ }^{\circ} \mathrm{C}$ for $18 \mathrm{~h}$ and then slowly poured into a solution of aq. $\mathrm{Na}_{2} \mathrm{CO}_{3}(60 \mathrm{~mL})$. The resulting mixture was filtered and the colorless solid benzoate was washed with aq. $\mathrm{Na}_{2} \mathrm{CO}_{3}(2 \times 100 \mathrm{~mL})$. The solid was dissolved in $\mathrm{CH}_{2} \mathrm{Cl}_{2}(30 \mathrm{~mL})$ and the resulting solution was dried over $\mathrm{Na}_{2} \mathrm{SO}_{4}$. Evaporation gave the known benzoate 3 (2.3 g, 99\%) as a white solid. ${ }^{1}$

\section{Aldehyde (4).}
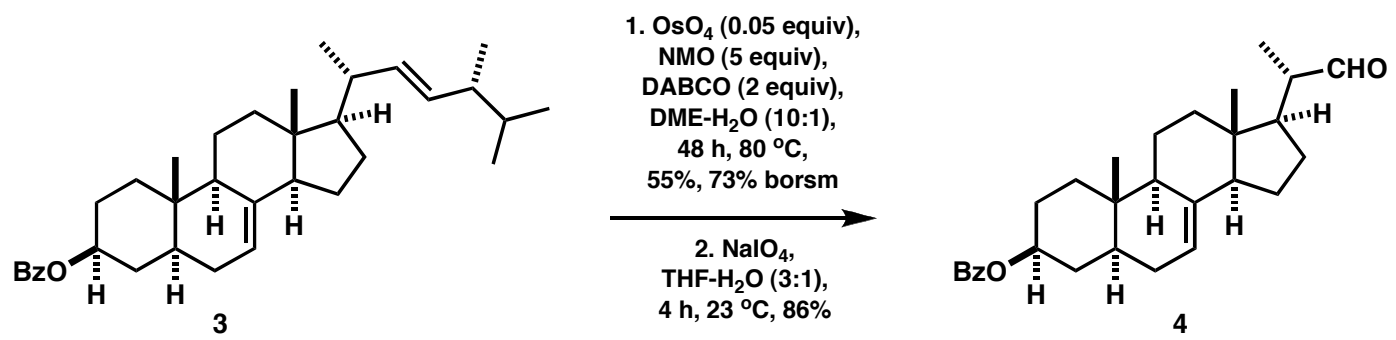

To a stirred suspension of benzoate 3 (173 $\mathrm{mg}, 0.344 \mathrm{mmol})$ in DME (1.5 mL) was added NMO (201 mg, $1.72 \mathrm{mmol})$ and DABCO (77 mg, $0.688 \mathrm{mmol})$. To this resulting 
suspension was added $\mathrm{OsO}_{4}\left(0.172 \mathrm{~mL}, 0.1 \mathrm{M}\right.$ in $\left.\mathrm{H}_{2} \mathrm{O}, 0.0172 \mathrm{mmol}\right)$ at $23{ }^{\circ} \mathrm{C}$ and the mixture was heated at $80{ }^{\circ} \mathrm{C}$ for $48 \mathrm{~h}$. (at ca. $75{ }^{\circ} \mathrm{C}$, all materials are fully dissolved) The mixture was cooled to $23{ }^{\circ} \mathrm{C}$ and saturated aq. $\mathrm{Na}_{2} \mathrm{SO}_{3}(1.5 \mathrm{~mL})$ is added. The two phases were separated and the aqueous phase was extracted with $\mathrm{CH}_{2} \mathrm{Cl}_{2}(3 \times 2 \mathrm{~mL})$. The combined organic extracts were dried over $\mathrm{Na}_{2} \mathrm{SO}_{4}$ and concentrated to dryness. Purification by flash chromatography (hexanes/EtOAc; 7:3) afforded benzoate 3 (31 mg, $18 \%$ ) and the desired 22,23-diol (100 mg, 55\%). The diol (400 mg, $0.745 \mathrm{mmol})$ was dissolved in THF- $\mathrm{H}_{2} \mathrm{O}(3: 1)(7.4 \mathrm{~mL}), \mathrm{NaIO}_{4}(478 \mathrm{mg}, 2.23 \mathrm{mmol})$ was added and the resulting suspension was stirred for $4 \mathrm{~h}$. The mixture was diluted with $\mathrm{H}_{2} \mathrm{O}(10 \mathrm{~mL})$ and the aqueous phase was extracted with $\mathrm{CH}_{2} \mathrm{Cl}_{2}(3 \times 10 \mathrm{~mL})$. The $\mathrm{CH}_{2} \mathrm{Cl}_{2}$ extract was dried over $\mathrm{Na}_{2} \mathrm{SO}_{4}$ and concentrated to dryness. The residue was purified by flash chromatography (hexanes/EtOAc; 9:1) to afford the known aldehyde 4 (280 mg, 86\%) as a white solid. ${ }^{1}$

\section{Propionate (5).}
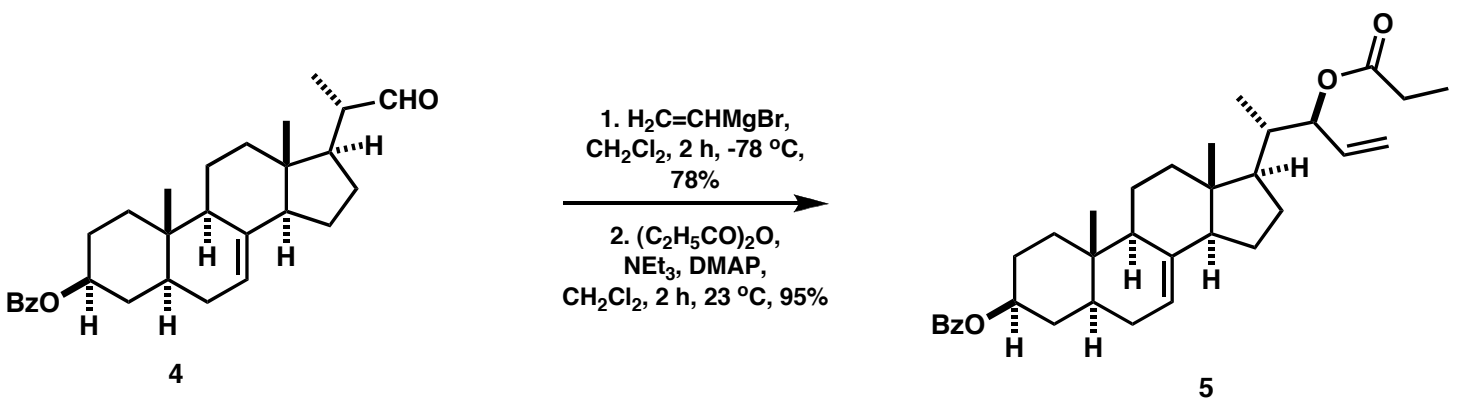

To a stirred solution of aldehyde $4(50 \mathrm{mg}, 0.115 \mathrm{mmol})$ in $\mathrm{CH}_{2} \mathrm{Cl}_{2}(1 \mathrm{~mL})$ was slowly added $\mathrm{H}_{2} \mathrm{C}=\mathrm{CHMgBr}(0.138 \mathrm{~mL}, 1 M$ in $\mathrm{THF}, 0.138 \mathrm{mmol})$ at $-78{ }^{\circ} \mathrm{C}$. The resulting solution was stirred at that temperature for $2 \mathrm{~h}$ and then treated with saturated aq. $\mathrm{NH}_{4} \mathrm{Cl}$ $(1 \mathrm{~mL})$. The aqueous phase was extracted with $\mathrm{CH}_{2} \mathrm{Cl}_{2}(3 \times 2 \mathrm{~mL})$ and the organic phase was dried with $\mathrm{Na}_{2} \mathrm{SO}_{4}$ and concentrated to dryness. The residue was purified by flash chromatography (hexanes/EtOAc; 7:3) to give the desired alcohol (40 mg, 78\%) as a white solid. $[\alpha]_{\mathrm{D}}-6.3\left(c\right.$ 0.24, $\left.\mathrm{CHCl}_{3}\right)$; m.p. $177{ }^{\circ} \mathrm{C} ;{ }^{1} \mathrm{H}$ NMR $\left(500 \mathrm{MHz}, \mathrm{CDCl}_{3}\right) \delta 8.04$ (d, 2H, $J=7.4 \mathrm{~Hz}), 7.54$ (t, 1H, $J=7.3 \mathrm{~Hz}), 7.42$ (t, 2H, $J=7.8 \mathrm{~Hz}), 5.87$ (m, 1H), 5.14$5.27(\mathrm{~m}, 3 \mathrm{H}), 4.95(\mathrm{~m}, 1 \mathrm{H}), 4.28(\mathrm{~s}, 1 \mathrm{H}), 2.02-1.84(\mathrm{~m}, 6 \mathrm{H}), 1.84-1.70(\mathrm{~m}, 3 \mathrm{H}), 1.61(\mathrm{~m}$, 4H), $1.50(\mathrm{~m}, 5 \mathrm{H}), 1.41-1.19(\mathrm{~m}, 4 \mathrm{H}), 0.90(\mathrm{~d}, 3 \mathrm{H}, J=6.8 \mathrm{~Hz}), 0.86(\mathrm{~s}, 3 \mathrm{H}) ; 0.56(\mathrm{~s}, 3 \mathrm{H})$; 
${ }^{13} \mathrm{C}$ NMR $\left(125 \mathrm{MHz}, \mathrm{CDCl}_{3}\right) \delta 166.3,141.3,139.5,132.9,131.1,129.7(2), 128.4(2)$, $117.7,113.9,74.4,74.3,55.1,52.6,49.4,43.5,41.5,40.3,39.6,37.0,34.5,34.1,29.7$, 27.8, 27.7, 23.1, 21.7, 13.2, 12.2, 12.0; IR (film, $\mathrm{cm}^{-1}$ ) 2942, 1711, 1449, 1323, 1264, 1116; HRMS calcd for $\mathrm{C}_{31} \mathrm{H}_{42} \mathrm{O}_{3} \mathrm{~K}\left(\mathrm{M}+\mathrm{K}^{+}\right) 501.2765$ found: 501.2802 .

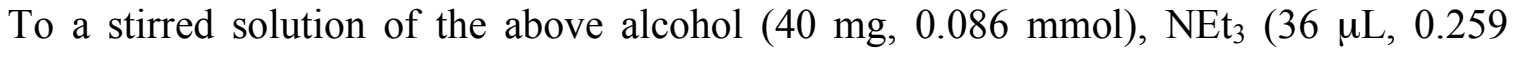
mmol) and DMAP (1 mg, $10 \mathrm{~mol} \%)$ in $\mathrm{CH}_{2} \mathrm{Cl}_{2}(1 \mathrm{~mL})$ was added propionic anhydride $(16 \mu \mathrm{L}, 0.129 \mathrm{mmol})$ at $23{ }^{\circ} \mathrm{C}$. The resulting solution was stirred for $2 \mathrm{~h}$ at that temperature and treated with saturated aq. $\mathrm{NH}_{4} \mathrm{Cl}(1 \mathrm{~mL})$. The aqueous phase was extracted with $\mathrm{CH}_{2} \mathrm{Cl}_{2}(3 \mathrm{x} \quad 1 \mathrm{~mL})$ and the extract was dried with $\mathrm{Na}_{2} \mathrm{SO}_{4}$ and concentrated to dryness. The residue was purified by flash chromatography (hexanes/EtOAc; 9:1) to give the propionate $5(43 \mathrm{mg}, 95 \%)$ as a white solid. $[\alpha]_{\mathrm{D}}-20.1$ (c 0.85, $\mathrm{CHCl}_{3}$ ); m.p. 167-170 ${ }^{\circ} \mathrm{C} ;{ }^{1} \mathrm{H}$ NMR (500 MHz, $\left.\mathrm{CDCl}_{3}\right) \delta 8.03$ (d, 2H, $J=7.7$ $\mathrm{Hz}), 7.53(\mathrm{t}, 1 \mathrm{H}, J=7.3 \mathrm{~Hz}), 7.42$ (t, 2H, $J=7.3 \mathrm{~Hz}), 5.76(\mathrm{~m}, 1 \mathrm{H}), 5.42(\mathrm{~s}, 1 \mathrm{H}), 5.17-$ $5.11(\mathrm{~m}, 2 \mathrm{H}), 4.95(\mathrm{~s}, 1 \mathrm{H}), 2.39(\mathrm{~m}, 2 \mathrm{H}), 2.05-1.78(\mathrm{~m}, 8 \mathrm{H}), 1.78-1.32(\mathrm{~m}, 10 \mathrm{H}), 1.32-$ $1.10(\mathrm{~m}, 6 \mathrm{H}$, containing a t, $J=7.32 \mathrm{~Hz}), 0.99(\mathrm{~d}, 3 \mathrm{H}, J=6.8 \mathrm{~Hz}+1 \mathrm{H}), 0.86(\mathrm{~s}, 3 \mathrm{H})$; 0.55 (s, 3H); ${ }^{13} \mathrm{C}$ NMR (125 MHz, $\left.\mathrm{CDCl}_{3}\right) \delta 174.0,166.3,139.3,136.6,132.9,131.1$, 129.7(2), 128.4(2), 117.8, 115.3, 76.4, 74.2, 55.1, 52.6, 49.5, 43.5, 40.7, 40.3, 39.6, 37.1, 34.4, 34.1, 29.7, 28.0, 27.9, 27.8, 23.1, 21.7, 13.5, 13.2, 11.9, 9.6; IR (film, cm ${ }^{-1}$ ) 2941, $1734,1711,1321,1273,1177,1114$.

\section{5-(R)-acid (6).}
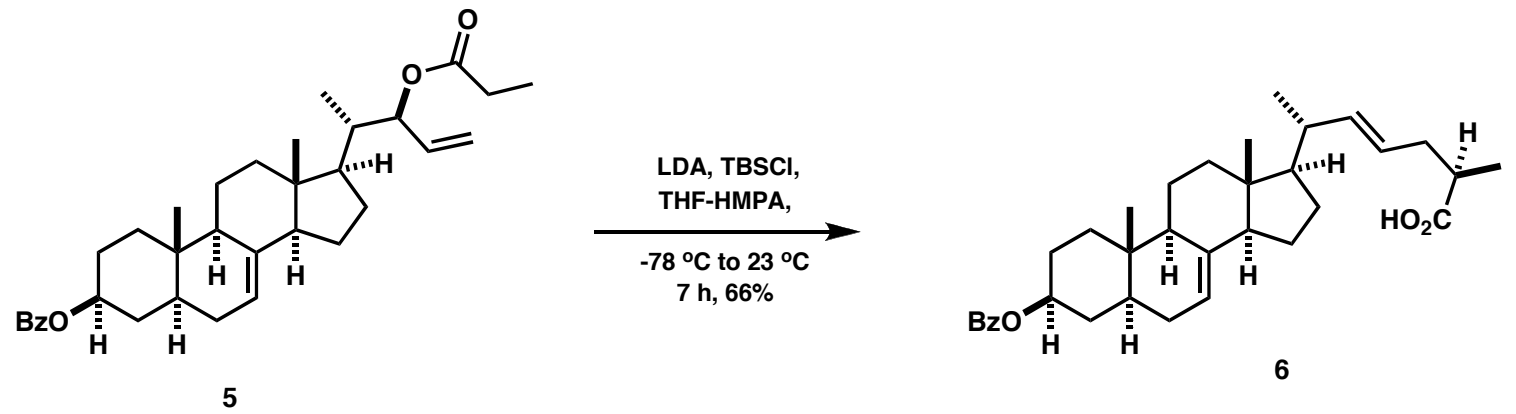

To a stirred solution of diisopropylamine $(67 \mu \mathrm{L}, 0.481 \mathrm{mmol})$ in THF $(2.2 \mathrm{~mL})$ was added $n$-BuLi $(171 \mu \mathrm{L}, 2.7 M$ in hexanes, $0.462 \mathrm{mmol})$ at $0{ }^{\circ} \mathrm{C}$. The solution was stirred at $0{ }^{\circ} \mathrm{C}$ for $15 \mathrm{~min}$ and cooled to $-78{ }^{\circ} \mathrm{C}$. HMPA $(960 \mu \mathrm{L})$ and THF $(960 \mu \mathrm{L})$ were then successively added. The solution became light yellow and after $10 \mathrm{~min}$, a solution of 
propionate $5(50 \mathrm{mg}, 0.0963 \mathrm{mmol})$ in THF $(300 \mu \mathrm{L})$ was slowly added. The resulting solution was stirred at $-78{ }^{\circ} \mathrm{C}$ for $45 \mathrm{~min}$ by which time the color became bright yellow. A solution of TBSCl $(116 \mathrm{mg}, 0.774 \mathrm{mmol})$ in THF $(300 \mu \mathrm{L})$ was then added. The solution became light yellow and after $15 \mathrm{~min}$ at $-78{ }^{\circ} \mathrm{C}$ the reaction mixture was gradually warmed to $23{ }^{\circ} \mathrm{C}$ over $2 \mathrm{~h}$. The solution was then stirred at $23{ }^{\circ} \mathrm{C}$ for $7 \mathrm{~h}$ and quenched with $1 N \mathrm{HCl}(2 \mathrm{~mL})$. The aqueous phase was extracted with EtOAc $(3 \mathrm{x} 5 \mathrm{~mL})$. The extract was dried over $\mathrm{Na}_{2} \mathrm{SO}_{4}$ and concentrated to dryness. The residue was purified by flash chromatography (hexanes/EtOAc; 9:1 $\rightarrow$ 7:3) to afford the corresponding acid 6 (33 mg, 66\%) as a white solid. $[\alpha]_{\mathrm{D}}-15.3\left(c 0.06, \mathrm{CHCl}_{3}\right)$; m.p. 165-167 ${ }^{\circ} \mathrm{C} ;{ }^{1} \mathrm{H}$ NMR (500 $\left.\mathrm{MHz} \mathrm{CDCl}_{3}\right) \delta 8.03(\mathrm{~d}, 2 \mathrm{H}, J=6.8 \mathrm{~Hz}), 7.54(\mathrm{t}, 1 \mathrm{H}, J=7.3 \mathrm{~Hz}), 7.42(\mathrm{t}, 2 \mathrm{H}, J=7.3$ Hz), $5.31(\mathrm{~m}, 2 \mathrm{H}), 5.16(\mathrm{~s}, 1 \mathrm{H}), 4.94(\mathrm{~m}, 1 \mathrm{H}), 2.50(\mathrm{~m}, 1 \mathrm{H}), 2.32(\mathrm{~m}, 1 \mathrm{H}), 2.00(\mathrm{~m}, 3 \mathrm{H})$, $1.88(\mathrm{~m}, 2 \mathrm{H}), 1.79(\mathrm{~m}, 2 \mathrm{H}), 1.60(\mathrm{~m}, 2 \mathrm{H}) ; 1.51(\mathrm{~m}, 3 \mathrm{H}), 1.38(\mathrm{~m}, 2 \mathrm{H}), 1.25(\mathrm{~m}, 4 \mathrm{H}), 1.15$ $(\mathrm{d}, 3 \mathrm{H}, J=6.8 \mathrm{~Hz}), 1.01(\mathrm{~d}, 3 \mathrm{H}, J=6.8 \mathrm{~Hz}), 0.86(\mathrm{~s}, 3 \mathrm{H}), 0.55(\mathrm{~s}, 3 \mathrm{H}) ;{ }^{13} \mathrm{C} \mathrm{NMR}(125$ $\left.\mathrm{MHz}, \mathrm{CDCl}_{3}\right) \delta 181.5,166.3,140.0,139.6,132.9,131.1,129.7,128.4,123.9,117.6$, 74.3, 55.8, 55.2, 49.5, 43.5, 40.6, 40.3, 39.7, 39.6, 37.1, 36.7, 34.5, 34.1, 29.7, 28.3, 27.8, 23.1, 21.7, 20.9, 16.4, 13.2, 12.3; IR (film, $\mathrm{cm}^{-1}$ ) 2949, 1713, 1700, 1652, 1558, 1456, 1277, 1117; MS (ES +) m/z (\%): $519.3\left(\mathrm{M}+\mathrm{H}^{+}, 100\right)$.

\section{5-(R)-dafachronic acid A (2).}
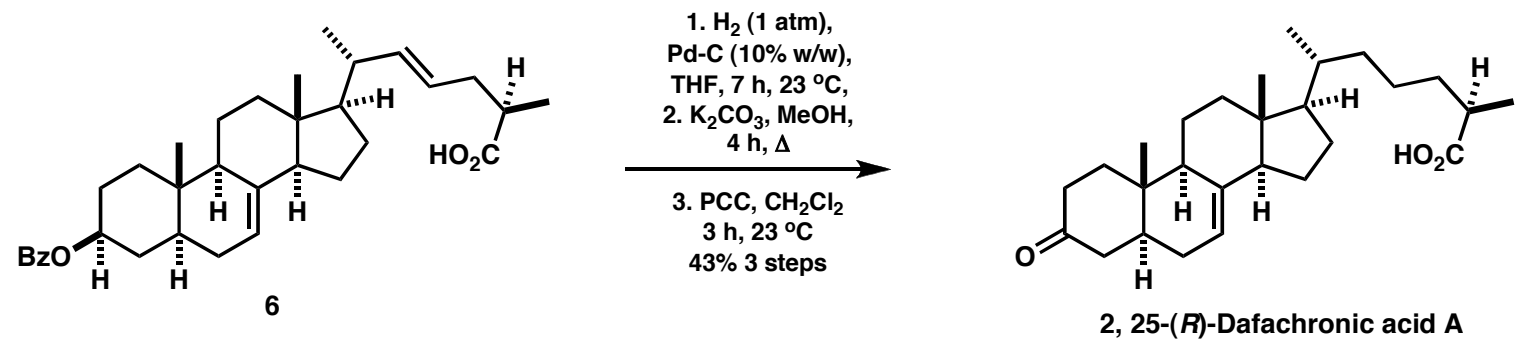

To a stirred solution of the above acid $6(30 \mathrm{mg}, 0.0578 \mathrm{mmol})$ in THF $(1.5 \mathrm{~mL})$ was added $\mathrm{Pd} / \mathrm{C}(5 \mathrm{mg}, 10 \% \mathrm{w} / \mathrm{w})$. A hydrogen-filled balloon (1 atm) was placed over the solution and the mixture was stirred for $7 \mathrm{~h}$, by which time NMR of an aliquot indicated that the reaction was completed. The mixture was filtered through a pad of Celite ${ }^{\circledR}$ and washed with EtOAc $(5 \mathrm{~mL})$. Evaporation gave the corresponding acid which was taken directly to the debenzoylation step. To a stirred solution of the above acid (20 $\mathrm{mg}, 0.038$ $\mathrm{mmol})$ in $\mathrm{MeOH} / \mathrm{CH}_{2} \mathrm{Cl}_{2}(5: 1)(0.5 \mathrm{~mL})$ was added $\mathrm{K}_{2} \mathrm{CO}_{3}(5.2 \mathrm{mg}, 0.038 \mathrm{mmol})$ at $23{ }^{\circ} \mathrm{C}$ 
and the solution was then refluxed for $4 \mathrm{~h}$. The reaction was quenched by addition of $3 \mathrm{~N}$ $\mathrm{HCl}(0.5 \mathrm{~mL})$ and the aqueous phase was extracted with $\mathrm{CH}_{2} \mathrm{Cl}_{2}(3 \times 3 \mathrm{~mL})$. The organic phase was dried over $\mathrm{Na}_{2} \mathrm{SO}_{4}$ and concentrated to dryness. The residue was purified by flash chromatography (hexanes/EtOAc; 7:3 $\rightarrow 5: 5$ ) to afford the corresponding hydroxyacid as a white solid which was then dissolved in $\mathrm{CH}_{2} \mathrm{Cl}_{2}(1 \mathrm{~mL})$. PCC $(10 \mathrm{mg}$, $0.041 \mathrm{mmol}$ ) was then added. The solution was stirred at $23{ }^{\circ} \mathrm{C}$ for $3 \mathrm{~h}$ by which time TLC indicated that the oxidation was completed. Citric acid $(1 M, 1 \mathrm{~mL})$ was added to the solution and the two resulting phases were separated. The aqueous phase was extracted with $\mathrm{CH}_{2} \mathrm{Cl}_{2}(10 \times 2 \mathrm{~mL})$. The extract was dried over $\mathrm{Na}_{2} \mathrm{SO}_{4}$ and concentrated to dryness. The residue was purified by flash chromatography $\left(\mathrm{CH}_{2} \mathrm{Cl}_{2} / \mathrm{MeOH} ; 95: 5\right)$ to give 25-(R)-dafachronic acid A 2 (10 mg, 43\% over 3 steps) as a white solid. $[\alpha]_{\mathrm{D}}+18.4(c$ 2.0, $\left.\mathrm{CDCl}_{3}\right)$; m.p. $139-141{ }^{\circ} \mathrm{C} ;{ }^{1} \mathrm{H}$ NMR $\left(500 \mathrm{MHz}, \mathrm{CDCl}_{3}\right) \delta 5.16(\mathrm{~s}, 1 \mathrm{H}), 2.45(\mathrm{~m}, 1 \mathrm{H})$, $2.40(\mathrm{dd}, 1 \mathrm{H}, J=5.8$ and $14.6 \mathrm{~Hz}), 2.25(\mathrm{~m}, 3 \mathrm{H}), 2.11(\mathrm{~m}, 1 \mathrm{H}), 2.05(\mathrm{~m}, 1 \mathrm{H}), 1.81(\mathrm{~m}$, $5 \mathrm{H}), 1.78-1.58(\mathrm{~m}, 4 \mathrm{H}), 1.52(\mathrm{~m}, 3 \mathrm{H}), 1.48-1.32(\mathrm{~m}, 7 \mathrm{H}), 1.30-1.18(\mathrm{~m}, 5 \mathrm{H}), 1.16(\mathrm{~d}, 3 \mathrm{H}$, $J=6.8 \mathrm{~Hz}), 1.01(\mathrm{~m}, 1 \mathrm{H}), 0.90(\mathrm{~d}, 3 \mathrm{H}, J=6.8 \mathrm{~Hz}), 0.54(\mathrm{~s}, 3 \mathrm{H}) ;{ }^{13} \mathrm{C} \mathrm{NMR}(125 \mathrm{MHz}$, $\left.\mathrm{CDCl}_{3}\right) \delta 212.4,182.7,139.7,117.2,56.2,55.1,49.0,44.4,43.5,43.0,39.6,39.4,38.9$, $38.3,36.2,35.8,34.5,34.0,30.2,28.1,23.9,23.1,18.9,16.9,12.6,12.1$; HRMS calcd for $\mathrm{C}_{27} \mathrm{H}_{42} \mathrm{O}_{3}\left(\mathrm{M}-\mathrm{H}^{+}\right) 413.3061$ found: 413.3009 .

\section{Reference.}

Moreau, J. P.; Aberhart, D. J.; Caspi, E. J. Org. Chem. 1974, 39, 2018-2023. 
ST

4. Copies of selected ${ }^{1} \mathrm{H}$ and ${ }^{13} \mathrm{C}$ NMR spectras.

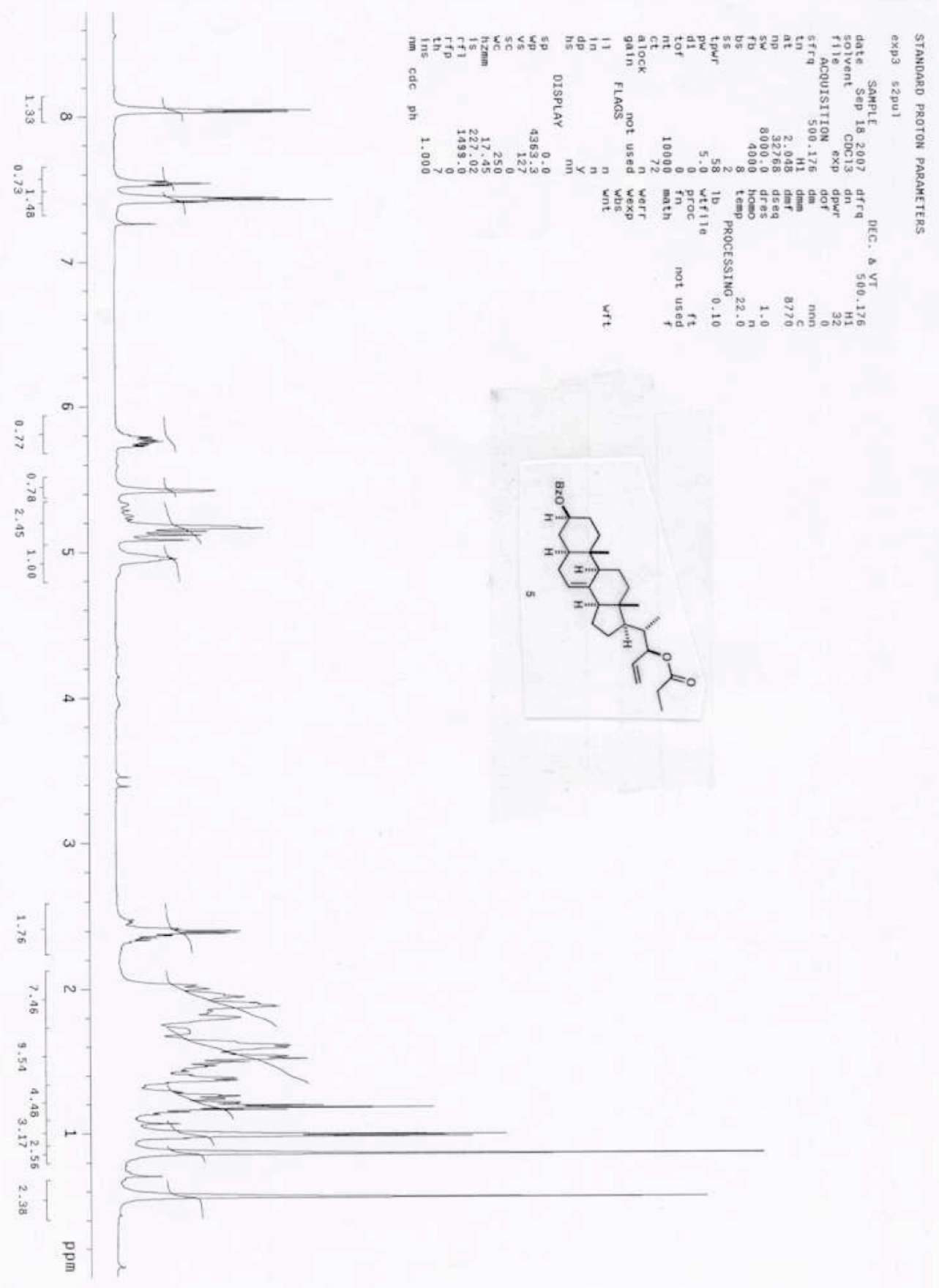



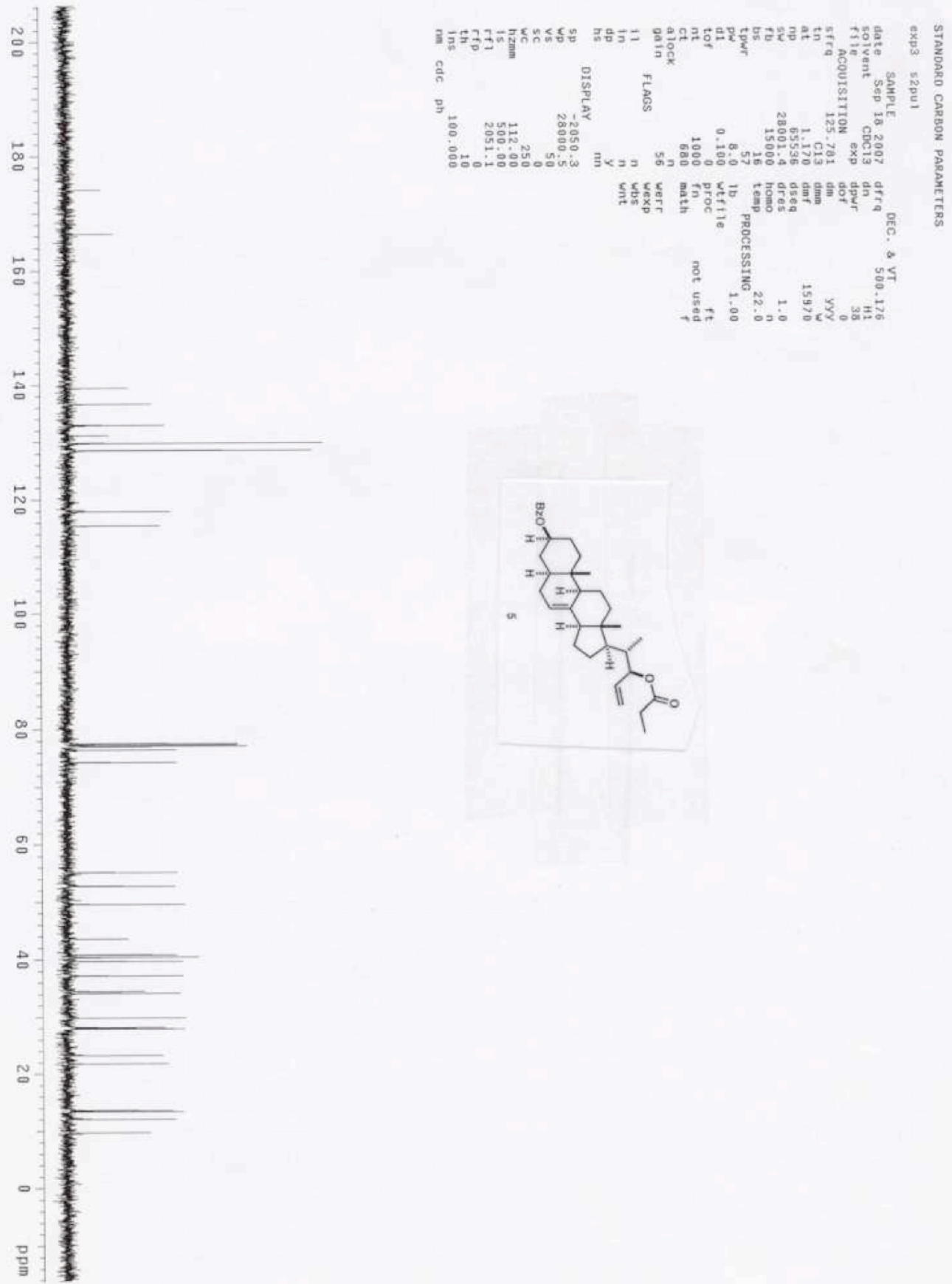


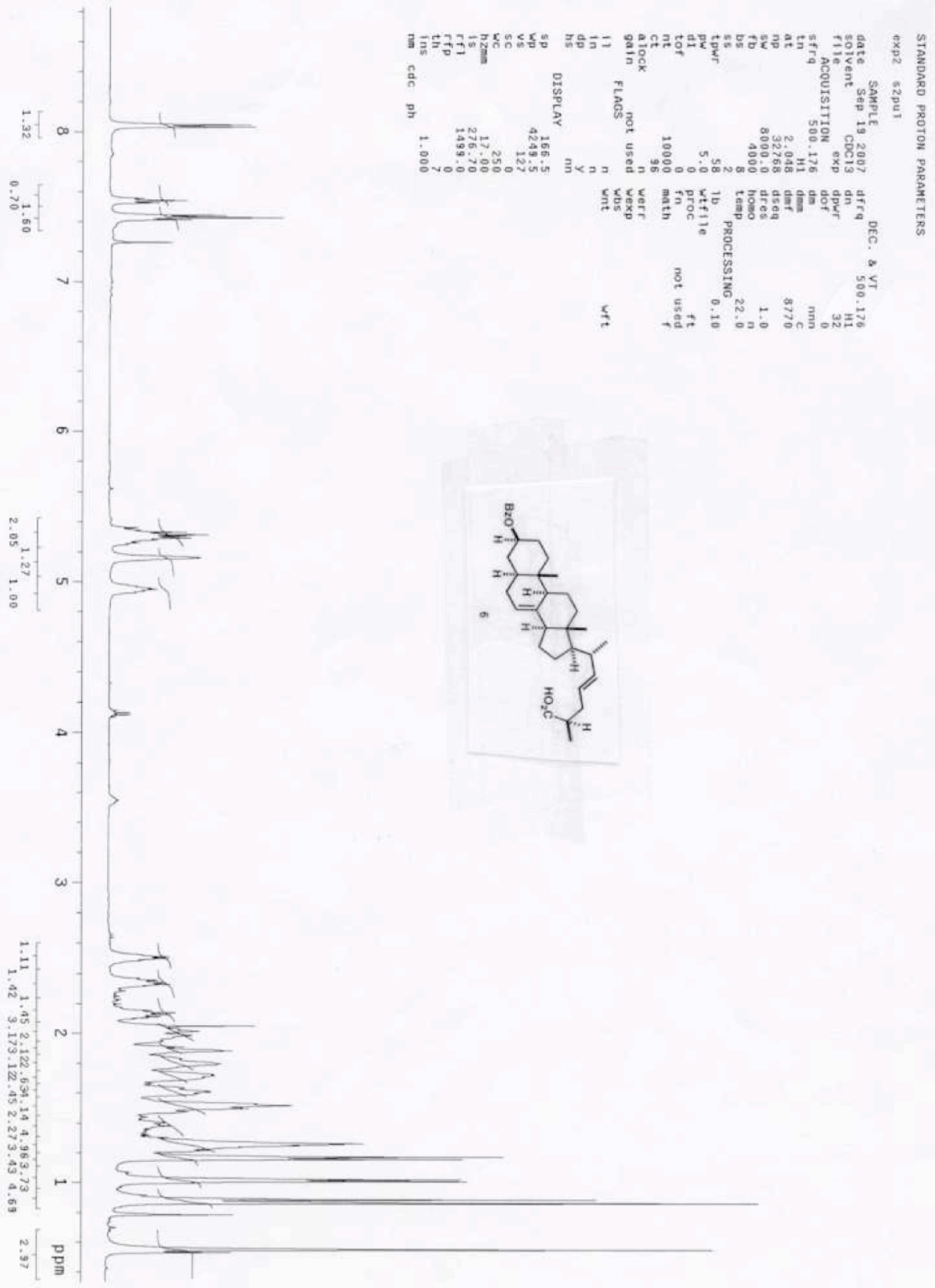



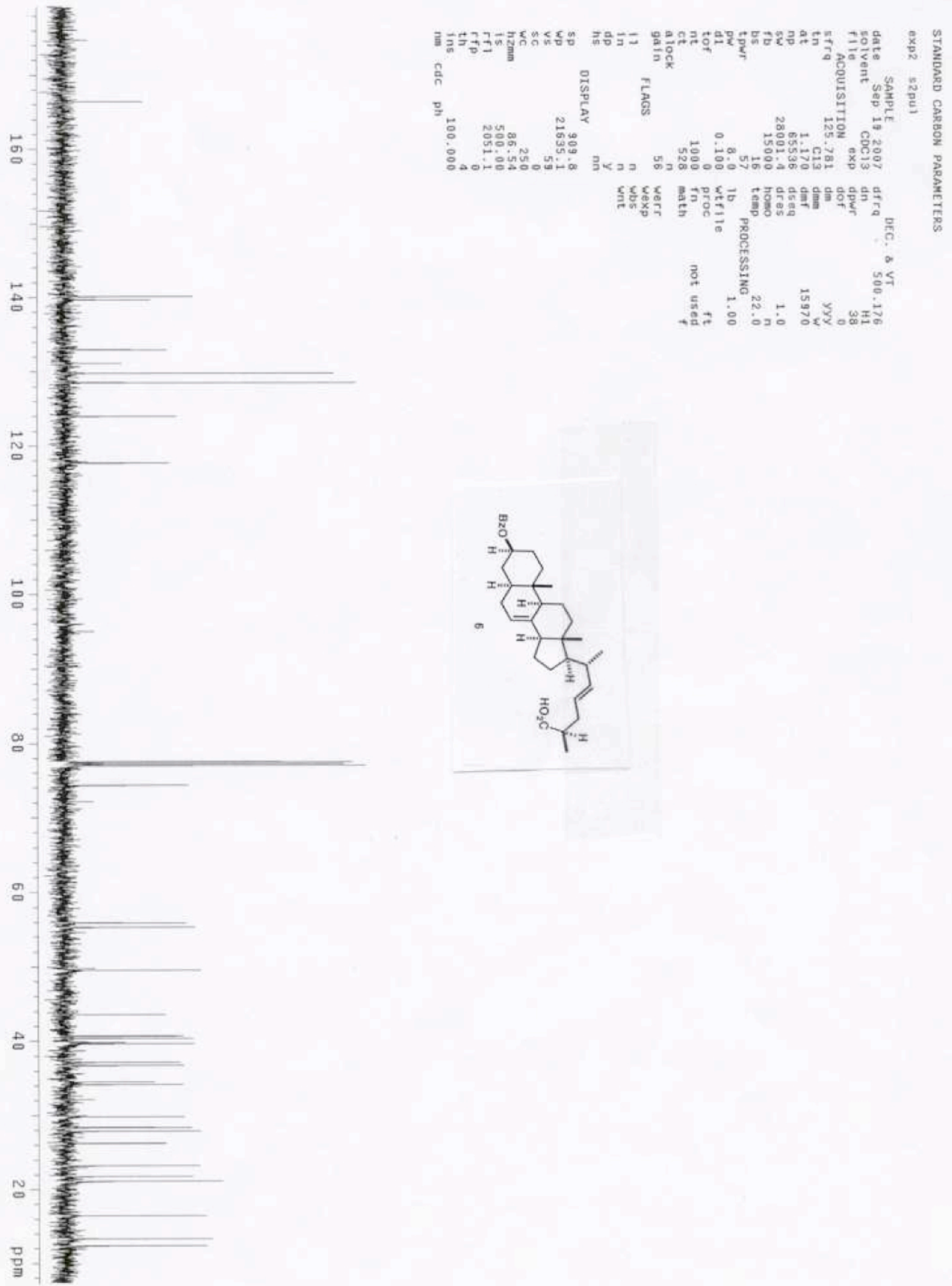


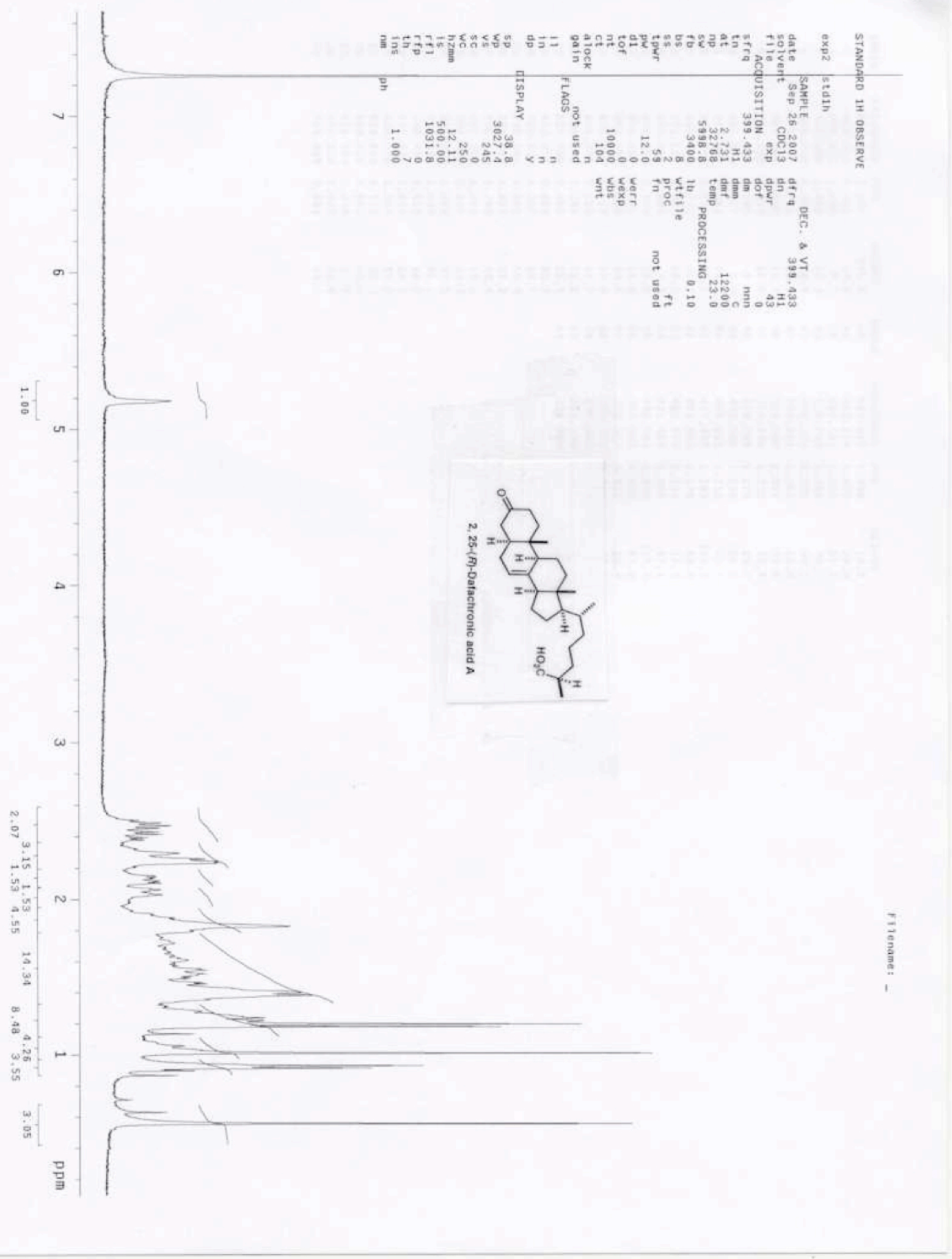




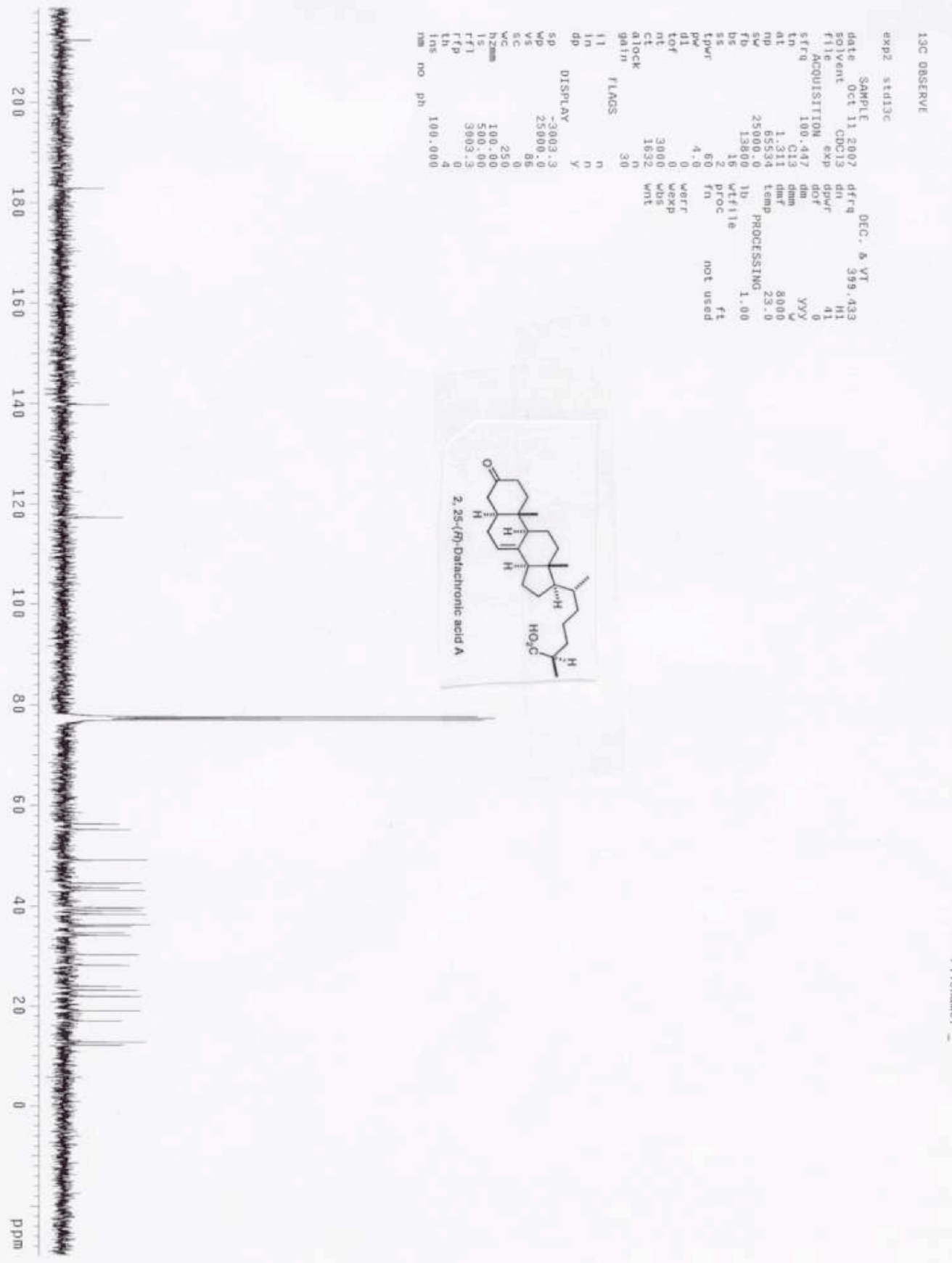

